\begin{tabular}{l|l} 
Jurnal Eksplorasi Akuntansi & $\begin{array}{l}\text { ISSN : 2656-3649 (Online) } \\
\text { Vol. 2, No 4, Seri E, November 2020, Hal 3828-3839://jea.ppj.unp.ac.id/index.php/jea/issue/view/33 }\end{array}$
\end{tabular}

\title{
Pengaruh Profitabilitas, Kualitas Laba Dan Keputusan Investasi Terhadap Nilai Perusahaan
}

\author{
Reza Refki Tanggo ${ }^{1}$, Salma Taqwa ${ }^{2}$ \\ 1Alumni Jurusan Akuntansi Fakultas Ekonomi Universitas Negeri Padang \\ Jurusan Akuntansi Fakultas Ekonomi Universitas Negeri Padang \\ *Korespondensi: rezarefkitanggo@gmail.com
}

\begin{abstract}
The purpose of this study was to analyze: (1) The effect of profitability on firm value. (2) The effect of earnings quality on firm value. (3) The effect of investment decisions on firm value. The population in this study are all manufacturing companies listed on the Indonesia Stock Exchange (BEI) in 2014-2018. While the sampling technique in this study is using purposive sampling technique with a total sample of 300 samples. The data analysis method used is multiple regression using SPSS 25 software. The results of this study indicate that: (1) profitability has a positive and significant effect on firm value with a significance of $0.000<0.05$. (2) earnings quality has a positive and insignificant effect on firm value with a significance of $0.757>0.05$. (3) investment decisions have a positive effect and not on the value of the company with a significance of $0.418>0.05$.
\end{abstract}

Keywords: Profitability, Earning Quality, Investment Decisions and Firm Value

\section{How to Cite (APA ${ }^{\text {th }}$ Style):}

Tanggo, R.R \& Taqwa, S. (2020). Pengaruh Profitabilitas, Kualitas Laba Dan Keputusan Investasi Terhadap Nilai Perusahaan. Jurnal Eksplorasi Akuntansi, 2(4), Seri E, 3828-2839.

\section{PENDAHULUAN}

Di era globalisasi seperti saat ini, dunia usaha semakin berkembang. Kemunculan berbagai perusahaan baik kecil maupun besar sudah merupakan fenomena yang biasa. Fenomena ini mengakibatkan munculnya tingkat persaingan antar perusahaan menjadi semakin ketat. Persaingan bagi perusahaan dapat berpengaruh positif yaitu dorongan untuk selalu meningkatkan mutu produk yang dihasilkan dan persaingan juga menimbulkan dampak negatif bagi perusahaan yaitu produk mereka akan tergusur dari pasar apabila perusahaan gagal meningkatkan mutu dan kualitas produk-produk yang dihasilkan. Dengan semakin ketatnya persaingan di era globalisasi ini peningkatan nilai perusahaan yang tinggi merupakan tujuan jangka panjang yang seharusnya dicapai perusahaan yang akan tercermin dari harga pasar sahamnya karena penilaian investor terhadap perusahaan dapat diamati melalui pergerakan harga saham perusahaan yang ditransaksikan di bursa untuk perusahaan yang sudah go public.

Indonesia menjadi negara ASEAN pertama yang dipercaya sebagai mitra resmi penyelenggaraan pameran teknologi manufaktur terbesar di dunia. Dari segi investasi, sektor industri manufaktur menjadi penyumbang investasi terbesar dalam 4 tahun terakhir (2014-2018) 
dan selalu menjadi yang teratas, yaitu sebesar 41,8 persen dari total realisasi investasi. Selain itu industri manufaktur juga berkontribusi pada nilai ekspor Indonesia yang mencapai 72,2 persen atau USD130 miliar pada tahun 2018 (kemenperin, 2019).

Menurut Zuliarni (2012) harga saham merupakan salah satu indikator keberhasilan pengelolaan perusahaan, jika harga saham suatu perusahaan mengalami kenaikan, maka investor atau calon investor menilai bahwa perusahaan berhasil dalam mengelola usahanya. Mengoptimalkan nilai perusahaan merupakan tujuan dari sebuah perusahaan (Salvatore, 2005). Perusahaan pastinya bertujuan untuk mensejahterakan pemegang saham dengan cara meningkatkan nilai perusahaan. Untuk menarik minat para investor perusaahn yang go public pastinya akan meningkatkan nilai perusahaan (Pramana \& Mustanda, 2016). Harga saham suatu perusahaan dapat mencerminkan nilai suatu perusahaan, hal itu dikarenakan harga saham memiliki hubungan positif dengan nilai persahaan. Memaksimalkan nilai perusahaan secara normatif meruapakan tujuan dari manajemen keuangan suatu perusahaan (Wiagustini, 2014).

Pada penelitian ini nilai perusahaan diukur menggunakan rasio Tobin's Q. Menurut Yeni \& Mayliza (2017) rasio Tobin'sQ dinilai bisa memberikan informasi yang paling baik, karena dalam rasio ini memasukkan semua unsur hutang dan modal saham perusahaan, tidak hanya saham biasa saja dan tidak hanya ekuitas perusahaan yang dimasukkan namun seluruh aset perusahaan. Jadi semakin besar nilai Tobin's Q menunjukkan bahwa perusahaan memiliki prospek pertumbuhan yang baik maka akan semakin besar kerelaan investor untuk mengeluarkan pengorbanan yang lebih untuk memiliki perusahaan tersebut (Sukamulja, 2004).

Dalam upaya meningkatkan nilai perusahaan maka harus ada kerja sama antara kedua belah pihak, yaitu manajemen perusahaan yang diwakili oleh manajer dengan pemegang saham perusahaan. Namun fakta yang sering terjadi adanya kontradiksi antara manajer perusahaan dengan pemegang saham. Ketika terdapat pemisahan antara pemilik dengan manajer disuatu perusahaan maka terdapat kemungkinan bahwa keinginan pemilik diabaikan. Inilah yang menyebabkan adanya masalah keagenan atau yang sering disebut agency problem (Jensen \& Meckling, 2012).

Terdapat beberapa faktor yang memengaruhi nilai perusahaan, salah satunya profitabilitas. Menurut Munawir (2010) profitabilitas adalah kemampuan perusahaan untuk menghasilkan laba selama periode tertentu. Profitabilitas merupakan faktor yang dapat mempengaruhi nilai perusahaan. Semakin baik kinerja keuangan suatu perusahaan pasti semakin baik pula nilai perusahaannya (Triagustina, et al. 2014 dan Harningsih et.al, 2019). Profitabilitas yang tinggi menunjukkan prospek perusahaan yang baik sehingga investor akan merespon positif sinyal tersebut dan nilai perusahaan akan meningkat (Sujoko \& Soebiataro, 2007). Brigham \& Houston (2010) menyatakan ROE adalah rasio bersih terhadap ekuitas biasa mengukur tingkat pengembalian atas investasi pemegang saham biasa.

Sucuahi \& Cambarihan (2016) menyatakan bahwa Profitabilitas berpengaruh positif terhadap nilai perusahaan dengan menggunakan Tobins'Q. Pendapat diatas diperkuat oleh Chen \& Chen (2011) mendapatkan hasil profitabilitas berpengaruh positif dan signifikan terhadap nilai perusahaan. Hal ini menunjukkan bahwa semakin besar profitabilitas suatu perusahaan, maka akan semakin besar nilai perusahaan. Selain profitabilitas, faktor yang mempengaruhi nilai perusahan yaitu kualitas laba. Menurut Machdar, et al. (2017) kualitas laba merupakan salah satu faktor penting untuk mengetahui nilai suatu perusahaan. Setiap perusahaan menginginkan kualitas laba yang baik karena akan meningkatkan nilai perusahaan. Nilai perusahaan yang tinggi akan meminta kepada para pemegang saham yang akan selalu menginvestasikan modalnya kepada perusahaan, karena akan meminta para pemegang saham yang akan mendapatkan saham yang dipindahkan dari investasi tersebut (Haruman, 2008). 
Menurut Lestari (2013), rendahnya kualitas laba di dalam laporan keuangan dapat membuat para pemakainya seperti manajemen perusahaan dan pihak eksternal terjadi kesalahan dalam pengambilan keputusan, sehingga akan membuat nilai perusahaan menurun. Menurut Chan, et al. (2006), ukuran suatu kualitas laba dapat memprediksi pergerakan harga saham untuk masa depan yang akan datang sehingga harga saham tersebut akan langsung mempengaruhi nilai perusahaan. Penelitian yang dilakukan oleh Dang, et al. (2020) menyatakan bahwa kualitas laba berpengaruh positif terhadap nilai perusahaan.

Faktor lain yang berkenaan dengan nilai perusahaan adalah keputusan investasi. Melakukan kegiatan investasi merupakan keputusan tersulit bagi manajemen perusahaan karena akan mempengaruhi nilai perusahaan. Mendapat laba yang besar dengan risiko yang dapat dikelola dengan harapan dapat mengoptimalkan nilai perusahaan merupakan tujuan dari keputusan investasi (Afzal \& Abdul, 2012).

Perusahaan melakukan investasi bertujuan untuk mendapatkan keuntungan di masa yang akan datang. Keputusan investasi mempunyai jangka waktu yang panjang, sehingga keputusan yang diambil harus dipertimbangkan dengan baik, karena mempunyai risiko berjangka panjang pula. Kesalahan dalam mengadakan peramalan akan dapat mengakibatkan kerugian bagi perusahaan. Dalam penlitian inikeputusan investasi diukur dengan Total Asset Growth (TAG).

Penelitian mengenai pengaruh keputusan investasi terhadap nilai perusahaan telah banyak dilakukan. Salah satunya penelitian yang dilakukan oleh Khairani (2018) yang membuktikan bahwa terdapat pengaruh positif signifikan terhadap nilai perusahaan. Sedangkan Niar (2019) yang menunjukan hasil bahwa keputusan investasi tidak berpengaruh terhadap nilai perusahaan.

Berangkat dari uraian di atas perlu dilakukan kajian mendalam mengenai: (1) Pengaruh profitabilitas terhadap nilai perusahaan. (2) Pengaruh kualitas laba terhadap nilai perusahaan (3) Pengaruh keputusan investasi terhadap nilai perusahaan.

\section{REVIEW LITERATUR}

\section{Teori Sinyal (Signalling Theory)}

Moniaga (2013) yang menyatakan bahwa teori sinyal merupakan suatu tindakan yang dapat diambil manajemen perusahaan dalam memberi petunjuk bagi para investor adalah melalui isyarat atau sinyal agar dapat mengetahui bagaimana manajemen memandang prospek perusahaan. Signalling theory sangat penting untuk menjelaskan tingkah laku pihak yang akan terlibat dalam sebuah kontrak dan pengambil keputusan terkait kontrak tersebut. Suatu pengungkapan dikatakan mengandung informasi apabila memperoleh reaksi pasar.

\section{Teori Keagenan (Agency Theory)}

Teori keagenan terjadi ketika adanya suatu kontrak antara principal dan agent untuk memberikan jasa demi kepentingan principal termasuk memberikan kekuasaan dalam pengambilan keputusan kepada agen (Belkaoi, 2007). Sedangkan Ichsan (2013) menyatakan hubungan keagenan merupakan suatu kontrak dimana satu atau lebih orang (principal) memerintah orang lain (agen) untuk melakukan jasa atas nama principal, serta principal memberi wewenang kepada agen membuat keputusan yang terbaik bagi principal.

\section{Teori Asimetri informasi (Asymmetric Information Theory)}

Menurut Pertiwi (2015) pihak luar perusahaan sering tidak memiliki akses atas informasi tentang prospek perusahaan sedangkan agen/manajer memiliki akses tersebut. Hal ini disebut dengan asimetri informasi. Pada umumny manajer lebih mengetahui kondisi dan prospek perusahaan di 
masa depan, tetapi manajer kurang memiliki pengetahuan tentang pasar saham dan tingkat bunga di masa depan. Jika seorang manajer mengetahui prospek perusahaan lebih baik dari analis atau investor itulah yang disebut dengan asymmetric information (Sartono, 2006)

\section{Nilai Perusahaan (Firm Value)}

Moniaga (2013) menyatakan bahwa nilai perusahaan merupakan persepsi investor terhadap perusahaan yang sering dikaitkan dengan harga saham. Harga saham yang tinggi akan membuat nilai perusahaan juga tinggi. Harga yang diperdagangkan di pasar disebut sebagai harga saham. Pandangan investor pada tingkat keberhasilan perusahaan dalam mengelola sumber daya yang ada di perusahaan disebut sebagai nilai perusahaan. Penelitian ini meneliti nilai perusahaan dengan pendekatan harga saham dengan menggunakan rasio Tobin's Q. Alasan memilih rasio Tobin'Q dalam penelitian ini untuk mengukur nilai perusahaan adalah karena penghitungan rasio Tobin's Q lebih rasional mengingat unsur-unsur kewajiban juga dimasukkan sebagai dasar penghitungan.

\section{Profitabilitas (Profitability) dengan Nilai Perusahaan}

Profitabilitas merupakan tingkat keuntungan bersih yang bisa diperoleh oleh perusahaan pada saat menjalankan operasi (Nurhayati, 2013). Hasil akhir dari sejumlah kebijakan dan keputusan manajemen perusahaan disebut dengan profitabilitas (Brigham et al., 2001). Signalling theory adalah sinyal yang diberikan oleh manajemen perusahaan kepada investor mengenai prospek perusahaan dimasa yang akan datang (Brigham \& Houston, 2010). Tingginya rasio profitabilitas yang dimiliki oleh perusahaan merupakan sebuah sinyal yang membuat para investor tertarik untuk menanamkan modalnya di perusahaan tersebut. Sudana (2011) dan Pousette, et al. (2014) menyatakan bahwa besar kecilnya laba pada suatu perusahaan akan berpengaruh terhadap nilai perusahaan yang bersangkutan, maka akan terjadi hubungan yang positif antara profitabilitas dengan harga saham, yang mana tingginya harga saham akan mempengaruhi nilai perusahaan.

\section{Kualitas Laba (Earning Quality) dengan Nilai Perusahaan}

Menurut Wulansari (2013) kualitas laba merupakan kualitas informasi laba yang dapat digunakan oleh investor untuk menilai perusahaan yang informasi informasi tersebut tersedia untuk publik yang mampu menunjukkan sejauh mana laba dapat mempengaruhi pengambilan keputusan. Laba yang berkualitas adalah laba yang dapat menggambarkan kinerja keuangan perusahaan yang sebenarnya (Irawati, 2012).

Salah satu sudut pandang dari teori agensi adalah bahwa besarnya kepemilikan saham oleh institusi dapat mengurangi potensi konflik (agency problem) antara manajer dan pihak lainnya yang akhirnya bisa meningkatkan nilai perusahaan (Maryanti, et al 2016). Wijayati (2015) menyatakan bahwa pemegang saham institusional memainkan peran kunci dalam mengurangi masalah keagenan karena mereka dapat memantau kinerja perusahaan dan tindakan manajer sehingga dapat mempengaruhi dalam pengambilan keputusan. Pemegang saham institusional juga sebagai perbandingan dengan pemegang saham lainnya yang memilih lebih aktif dan bekerja demi kepentingan terbaik pemegang saham.

\section{Keputusan Investasi (Investment Decisions) dengan Nilai Perusahaan}

Menurut Sutrisno (2012:5) keputusan investasi merupakan bagaimana manajer keuangan harus mengalokasikan dana ke dalam bentuk-bentuk investasi yang akan mendatangkan keuntungan di masa yang akan dating. Sedangkan menurut Sudana (2011:3) keputusan investasi 
merupakan keputusan keuangan tentang aktiva yang harus dibeli perusahaan.

Menurut Signaling theory, pengeluaran investasi memberikan sinyal positif mengenai pertumbuhan perusahaan di masa yang akan datang, sehingga dapat meningkatkan harga saham yang digunakan sebagai indikator nilai perusahaan (Ningsih dan Indarti (2012). Hasil penelitian dari Fajria (2015), Ayem \& Nugroho (2016) menunjukan bahwa keputusan investasi berpengaruh positif terhadap nilai perushaan. Dengan demikian berdasarkan literatur yang ada, terdapat alasan untuk memprediksi bahwa keputusan investasi mampu meningkatkan nilai perusahaan.

\section{PENELITIAN TERDAHULU}

Penelitian ini mengacu pada beberapa penelitian-penelitian terdahulu sebagai bahan referensi. Diantaranya Hari Purnama(2016) Ayem \&Nugroho (2016) Chen \& Chen (2011) Ngatemin, et al. (2018) Rachmawati, et al. (2015) Niar $(2019$ Dewi dan Devie (2017) Dang, et al (2020) Sari \& wijayanto (2015) Harningsih et.al (2019).

\section{METODOLOGI PENELITIAN}

\section{Jenis Penelitian}

Jenis penelitian yang digunakan dalam penelitian tergolong pada penelitian deskriptif kausatif. Penelitian kausatif adalah penelitian yang bertujuan untuk menunjukkan arah hubungan sebab akibat antara variabel bebas dengan variabel terikat (Sugiyono, 2016:56).

\section{Lokasi Penelitian}

Penelitian ini akan dilakukan di Kota Padang, Provinsi Sumatera Barat, yang pelaksanaannya berlangsung pada bulan Juli sampai November 2020.

\section{Sumber Data}

Berdasarkan dari sumber data yang diambil, data yang digunakan dalam penelitian ini merupakan data sekunder (secondary data). Menurut Indriantoro dan Supomo (2002) data sekunder merupakan sumber data penelitian yang diperoleh oleh peneliti secara tidak langsung melalui perantara. Jenis data yang digunakan dalam penelitian ini adalah data kuantitatif.

\section{Instrumen Penelitian}

Dalam penelitian kuantitatif yang menjadi instrumen atau alat penelitian adalah peneliti itu sendiri. sebagai instrument penelitian maka peneliti harus melakukan validasi terhadap metode kuantitatif serta penguasaan terhadap teori yang berhubungan dengan fokus penelitian yaitu pengaruh profitabilitas, kualitas laba dan keputusan investasi terhadap nilai perusahaan.

\section{Teknik Pengumpulan Data}

Data dari penelitian ini diambil dari laporan tahunan dan laporan keuangan perusahan yang diakses melalui situs resmi Bursa Efek Indonesia (BEI), situs resmi dari masing-masing perusahaan sampel, dan situs-situs lain yang dibutuhkan. Peneliti juga memperoleh data dengan cara mencari sumber informasi melalui buku-buku, makalah-makalah yaitu berkaitan dengan teori yang relevan bagi pembahasan masalah pada penelitian ini.

\section{HASIL DAN PEMBAHASAN}

Deskripsi variabel dalam statistik deskriptif yang digunakan dalam penelitian ini meliputi nilai minimum, maksimum, mean dan standar deviasi dari variabel penelitian. Statistik 
deskriptif menggambarkan karakter sampel yang digunakan dalam penelitian ini. Statistik deskriptif selengkapnya dalam penelitian ini ditampilkan dalam tabel 3 berikut:

Tabel 3. Deskripsi Statistik Variabel Penelitian

\begin{tabular}{lcrrrr}
\hline \multicolumn{5}{c}{ Descriptive Statistics } \\
\hline X1 & $\mathrm{N}$ & \multicolumn{1}{c}{ Minimum } & \multicolumn{1}{c}{ Maximum } & \multicolumn{1}{c}{ Mean } & \multicolumn{1}{c}{ Std. Deviation } \\
X2 & 300 & -.74 & 2.54 & .1241 & .28978 \\
X3 & 300 & -572.34 & 75.29 & -.8833 & 34.14974 \\
Y & 300 & -.40 & 4.19 & .1099 & .35337 \\
Valid N & 300 & .20 & 23.29 & 1.9362 & 2.96558 \\
(listwise) & 300 & & & & \\
\hline
\end{tabular}

\section{Sumber: Hasil Olahan SPSS 25}

Tabel 3 menjelaskan tentang deskripsi variabel penelitian. Penelitian ini dilakukan pada perusahaan manufaktur yang terdaftar di Bursa Efek Indonesia periode 2014-2018 dengan sampel sebanyak 300. Variabel penelitian ini meliputi nilai perusahaan (Y), profitabilitas (X1), kualitas laba (X2) dan keputusan investasi (X3). Berikut gambaran mengenai variabel yang akan diteliti dalam penelitian ini

\section{Uji Normalitas}

Tujuan uji normalitas adalah untuk mengetahui apakah distribusi sebuah data mengikuti atau mendekati distribusi normal. Secara rinci hasil pengujian normalitas dapat dilihat pada gambar berikut:

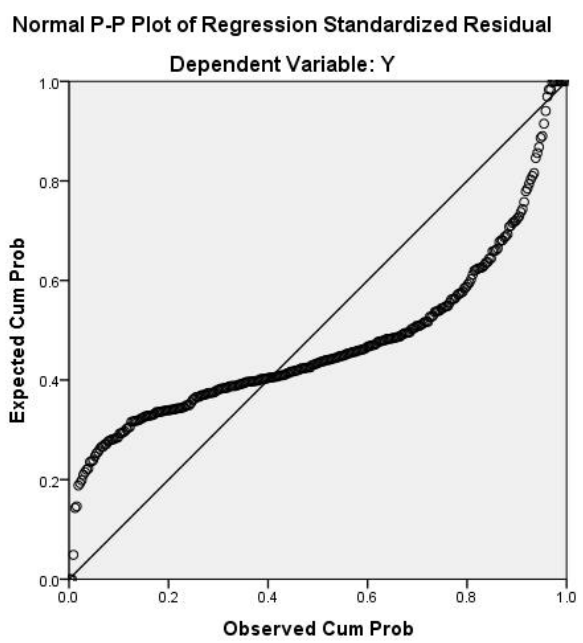

Gambar 2. Grafik Normal Probability PlotAwal

Pada gambar 2 dapat dilihat bahwa grafik normal probability plot menunjukkan pola grafik yang tidak normal. Hal ini terlihat dari titik yang tidak menyebar disekitar grafik normal. Oleh karena ini dapat disimpulkan bahwa model regresi tidak layak dipakai karena memenuhi tidak asumsi normalitas sehingga perlu dilakukan transformasi data. Berikut merupakan hasil dari transformasi Log terhadap variabel dependen nilai perusahaan $(\mathrm{Y})$. 


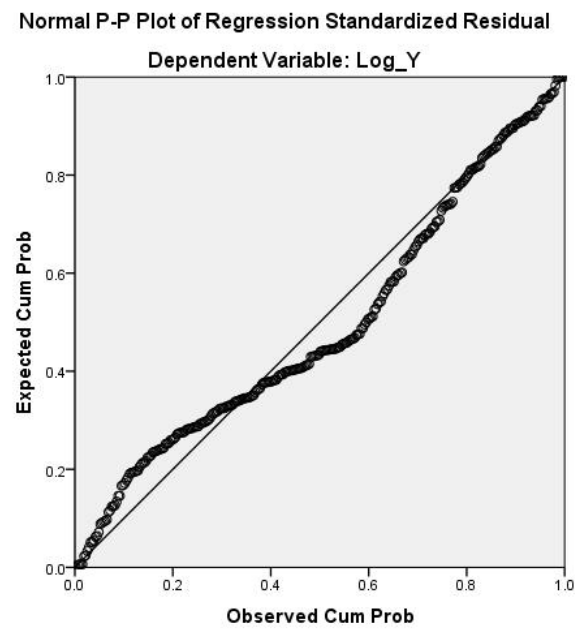

Gambar 3.Grafik Normal Probability PlotAkhir

Pada gambar 3 dapat dilihat bahwa grafik normal probability plot menunjukkan pola grafik yang normal. Hal ini terlihat dari titik-titik yang menyebar disekitar garisdiagonal dan penyebarannya mengikuti garis diagonal. Oleh karena ini dapatdisimpulkan bahwa model regresi layak diapakai karena memenuhi asumsi normalitas.

\section{Uji Multikolinearitas}

Uji multikolineritas bertujuan untuk mengetahui ada tidaknya variabel independen yang memiliki korelasi antar variabel independen lain dalam satu model. Model regresi yang baik seharusnya tidak terjadi korelasi diantara variabel independen. Multikolineritas diuji dengan melihat nilai Tolerance yang tidak kurang dari 0,1 dan nilai Variance Inflation Factor (VIF) yang tidak lebih dari 10 sehingga model dapat dikatakan terbebas dari multikolineritas. Hasil uji multikolinearitas dapat dilihat pada tabel 5 dibawah ini:

Tabel 4.Hasil Uji Multikolinearitas

\begin{tabular}{|c|c|c|c|}
\hline \multicolumn{4}{|c|}{ Coefficients $^{a}$} \\
\hline \multirow[b]{2}{*}{ Model } & & \multicolumn{2}{|c|}{ Collinearity Statistics } \\
\hline & & Tolerance & VIF \\
\hline \multirow[t]{4}{*}{1} & (Constant) & & \\
\hline & $\mathrm{X} 1$ & .999 & 1.001 \\
\hline & $\mathrm{X} 2$ & .999 & 1.001 \\
\hline & X3 & .999 & 1.001 \\
\hline \multicolumn{4}{|c|}{ a. Dependent Variable: Log_Y } \\
\hline
\end{tabular}

Berdasarkan tabel 4 di atas dapat dilihat bahwa model regresi tidak mengalami gangguan multikolinieritas. Hal ini tampak pada nilai tolerance masing-masing variabel lebih besar dari 10 persen $(0,1)$. Hasil perhitungan VIF juga menunjukkan bahwa nilai VIF masingmasing variabel kurang dari 10. Jadi dapat disimpulkan bahwa tidak ada multikolinieritas antar variabel bebas dalam model regresi tersebut.

\section{Uji Heteroskedastisitas}

Pengujian heteroskesdastisitas dilakukan untuk melihat apakah terdapat ketidaksamaan 
ragam dari residual satu ke pengamatan ke pengamatan yang lain. Kondisi heteroskedastisitas sering terjadi pada data cross section, atau data yang diambil dari beberapa responden pada suatu waktu tertentu. Model regresi yang memenuhi persyaratan adalah di mana terdapat kesamaan ragam dari residual satu pengamatan ke pengamatan yang lain tetap atau disebut homoskedastisitas.

Hasil uji heteroskedastisitas dari program SPSS dapat dilihat pada gambar 5 berikut ini:

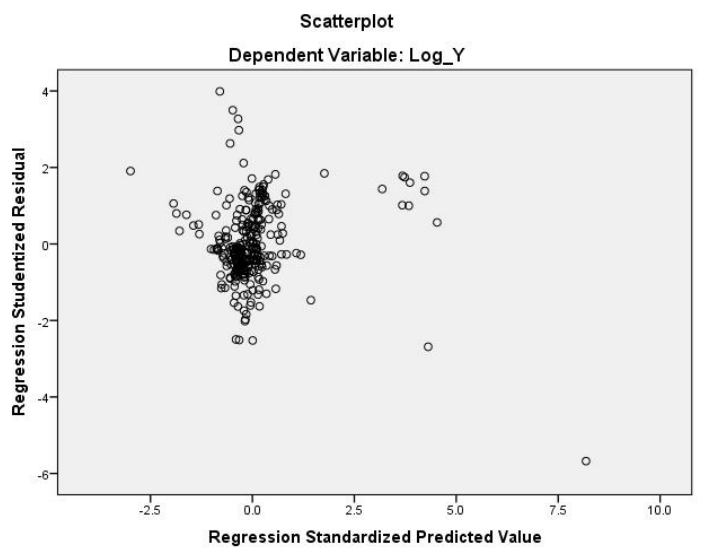

Gambar 4.Grafik scatter plot

Pada gambar 4 dapat dilihat bahwa titik-titik pada grafik scatterplot tidak mempunyai pola penyebaran yang jelas dan titik-titik tersebut menyebar di atas dan dibawah angka 0 pada sumbu Y. Hal ini menunjukkan bahwa tidak terdapat gangguan heteroskedastisitas pada model regresi.

\section{Uji Autokorelasi}

Uji autokorelasi bertujuan untuk menguji apakah dalam suatu model regresi linear ada korelasi antara kesalahan pengaganggu pada periode t-1 (sebelumnya). Jika terjadi korelasi maka dinamakan ada problem autokorelasi. Uji autokorelasi dapat dilihat dari nilai Durbin Watson. Apabila nilai Durbin Watson berada pada daerah dU sampai 4-dU dapat disimpulkan bahwa model regresi tidak mengandung autokorelasi. Berikut hasil uji autokorelasi ditunjukkan pada Tabel 5 .

Tabel 5. Hasil Uji Autokorelasi

\begin{tabular}{|c|c|c|c|c|c|}
\hline \multicolumn{6}{|c|}{ Model Summary ${ }^{\mathrm{b}}$} \\
\hline Model & $R$ & R Square & $\begin{array}{l}\text { Adjusted } \\
\text { Square }\end{array}$ & $\begin{array}{l}\text { RStd. Erro } \\
\text { Estimate }\end{array}$ & Durbin-Watson \\
\hline 1 & $.534^{\mathrm{a}}$ & .285 & .278 & .29018 & 825 \\
\hline \multicolumn{6}{|c|}{ a. Predictors: (Constant), X3, X2, X1 } \\
\hline \multicolumn{6}{|c|}{ b. Dependent Variable: Log_Y } \\
\hline
\end{tabular}

Berdasarkan hasil uji autokorelasi pada Tabel 5 diperoleh nilai durbin-watsnon stat yaitu sebesar 0,825 . Sedangkan nilai dU berdasarkan pada tabel Durbin Watson dengan $\mathrm{n}=300$ dan $\mathrm{k}=3$ yaitu 0,80398. Karena nilai Durbin Watson $(0,825)$ lebih besar dari nilai dU $(0,80398)$ dapat disimpulkan bahwa model tidak mengandung autokorelasi.

\section{Uji Analisis Regresi Linear Berganda}

Berdasarkan hasil regresi dengan menggunakan program SPSS, maka 
didapatkankoefisien regresi yang dapat dilihat pada tabel 6 berikut ini:

Tabel 6. Hasil Koefisien Regresi Linear Berganda

\begin{tabular}{|c|c|c|c|c|c|c|}
\hline \multirow[b]{2}{*}{ Model } & & \multicolumn{2}{|c|}{ Unstandardized Coefficients } & $\begin{array}{l}\text { Standardized } \\
\text { Coefficients }\end{array}$ & \multirow[b]{2}{*}{$\mathrm{t}$} & \multirow[b]{2}{*}{ Sig. } \\
\hline & & B & Std. Error & Beta & & \\
\hline 1 & (Constant) & .017 & .019 & & .889 & .375 \\
\hline & $\overline{\mathrm{X}} 1$ & .626 & .058 & .531 & 10.805 & .000 \\
\hline & $\overline{\mathrm{X} 2}$ & .000 & .000 & .015 & .310 & .757 \\
\hline & $\overline{\mathrm{X} 3}$ & .039 & .048 & .040 & .812 & .418 \\
\hline
\end{tabular}

a. Dependent Variable: Log_Y

\section{Sumber: Hasil Olahan SPSS 25}

Berdasarkan pada 6 maka didapatkan persamaan regresi linierberganda sebagai berikut:

$$
Y=0,017+0,626 \times 1+0,000 \times 2+0,039 \times 3+\text { error }
$$

Analisis koefesien determinasi dilakukan unutk mengetahui seberapa besar nilai persentase kontribusi variabel bebas terhadap variabel terikat.dari hasil perhitungan didapatkan nilai koefesien determinasi sebagai berikut:

Tabel 7.Hasil Koefisien Determinasi

\begin{tabular}{|c|c|c|c|c|c|}
\hline \multicolumn{6}{|c|}{ Model Summary ${ }^{b}$} \\
\hline Model & $\mathrm{R}$ & R Square & $\begin{array}{l}\text { Adjusted R } \\
\text { Square }\end{array}$ & $\begin{array}{l}\text { Std. Error of the } \\
\text { Estimate }\end{array}$ & Durbin-Watson \\
\hline 1 & $.534^{\mathrm{a}}$ & .285 & .278 & .29018 & .825 \\
\hline \multicolumn{6}{|c|}{ a. Predictors: (Constant), X3, X2, X1 } \\
\hline b. Dep & Variable & $\log _{-} Y$ & & & \\
\hline
\end{tabular}

Berdasarkan tabel 7dapat dilihat bahwa nilai Adjusted $\mathrm{R}^{2}$ adalah sebesar 0,278.Hal ini dapat diartikan bahwa variabel independen profitabilitas (X1), kualitas laba (X2), dan keputusan investasi (X3) dapat menjelaskan variabel dependennilai perusahaan (Y)sebesar 27,8\%, sedangkan sisanya diterangkan oleh faktor lain yang tidak diteliti.

\section{KESIMPULAN DAN SARAN \\ Kesimpulan}

Berdasarkan pada tujuan penelitian, rumusan masalah dan hasil penelitian dengan pembahasan yang telah di paparkan, maka dapat diambil kesimpulan dari penelitian ini sebagai berikut:

1. Profitabilitas berpengaruh positifdan signifikan terhadap nilai perusahaan manufaktur yang terdaftar di BEI. Hal ini menunjukkan bahwa profitabilitas berbanding lurus dengan nilai perusahaan. Jika profitabilitas mengalami peningkatan maka nilai perusahaan juga akan 
mengalami peningkatan, begitu pula sebaliknya.

2. Kualitas laba tidak berpengaruhsignifikan terhadap nilai perusahaan. jika memang terdapat pengaruh namun pengaruhnya itu kecil. Hal ini menunjukkan bahwa kualitas laba yang tinggi mampu untuk meningkatkan nilai perusahaan.

3. Keputusan Investasi tidak berpengaruh signifikan terhadap nilai perusahaan manufaktur yang terdaftar di BEI. Hal ini menunjukkan bahwa keputusan investasi memiliki pengaruh yang kecil namun belum mampu untuk meningkatkan nilai perusahaan.

\section{Saran}

1. Bagi Investor, sebaiknya mencari informasi yang cukup tentang nilai perusahaan manufaktur yang akan dipilih. Selain itu investor juga harus memperhatikan bagaimana profitabilitas perusahaan, bagaimana kualitas laba perusahaan, dan juga keputusan investasi pada perusahaan tersebut.

2. Bagi peneliti selanjutnya, penelitian ini dapat dijadikan sebagai bahan referensi untuk peneliti selanjutnya.Selain itu, diharapkan peneliti selanjutnya dapat melakukan penelitian lebih lanjut mengenai faktor-faktor yang mempengaruhi nilai perusahaan serta dapat menambah periode penelitian, mengganti objek penelitian serta menambah variabel penelitian lain.

3. Bagi Perusahaan, hendaknya lebih memperhatikan tingkat kesejahteraan investor karena perusahaan bertanggung jawab terhadap kesejahteraan Stakeholders.

\section{DAFTAR PUSTAKA}

Bambang Supomo dan Nur Indriantoro. (2002).Metodologi Penelitian Bisnis, Cetakan Kedua. Yogyakara; Penerbit BFEE UGM.

Bougie, \& Sekaran. (2013). Edisi 5, Research Methods for Business: A skill Building Approach. New York: John wiley.

Brigham, E. F., \& Houston, J. F. (2010). Manajemen Keuangan Edisi Kedelapan. In Erlangga Jakarta. https://doi.org/10.1016/0377-841X(78)90069-4

Brighman, Eugene F and Joel F. Houtson. (2001). Fundamenals of Financial Management, Ninth Edition, Horcourt College, United State of America.

Chan, K., Chan, L. K., Jegadeesh, N., \& Lakonishok, J. (2006). Earnings Quality and Stock Return. Journal of Business, 79(3), 1041-1082.

Chen, L. J., \& Chen, S. Y. (2011). The influence of profitability on firm value with capital structure as the mediator and firm size and industry as moderators. Investment Management and Financial Innovations. 8(3), 121-129.

Dang, H. N, Nguyen, T. T. C, dan Tran, D. M. (2020) The Impact Of Earnings Quality on Firm Value: The Case of Vietnam. Journal of Asian Finance, Economics and Business, 7(3), 63-72

Dang, H. N, Nguyen, T. T. C, dan Tran, D. M. (2020) The Impact Of Earnings Quality on Firm Value: The Case of Vietnam. Journal of Asian Finance, Economics and Business, 7(3), $63-72$

Harningsih, Sri; Agustin, Henri; Setiawan, Mia Angelina. (2019). Pengaruh Kinerja Keuangan Terhadap Nilai Perusahaan Dengan Pengungkapan CSR dan Kebijakan Dividen Sebagai Variabel Moderasi. Ranah Research: Journal of Multidisciplinary Research and Development. 1(2). 199-209.

Jensen, M., \& Meckling, W. (2012). Theory of the firm: Managerial behavior, agency costs, and ownership structure. In The Economic Nature of the Firm: A Reader, Third Edition. https://doi.org/10.1017/CBO9780511817410.023 
Jonathan, Machdar, N. M. (2018). Pengaruh Kualitas Laba Terhadap Nilai Perusahaan D engan Reaksi Pasar Sebagai Variabel Intervening. Jurnal Riset Manajemen dan Bisnis (JRMB), 3(1), 2581-2165.

Lestari, L. S. (2013). Pengaruh Earnings Management terhadap Nilai Perusahaan dimoderasi dengan Praktik Corporate Governance. Diponegoro Journal of Accounting, 2(3), 1-9

Moniaga, F. (2013). Struktur Modal, Profitabilitas dan Struktur Biaya Terhadap Nilai Perusahaan Industri Keramik, Porcelen Dan Kaca Periode 2007-2011. Jurnal Riset Ekonomi, Manajemen, Bisnis dan Akuntansi (EMBA), 1(4), 433-442.

Munawir. (2010). Analisa Laporan Keuangan Edisi 4. In Jakarta: Salemba Empat.

Ngatemin, Maksum, A., Erlina, \& Sirojuzilam. (2018). Effects of institutional ownership and profitability to firm value with the capital structure as intervening variable (empirical study at company tourism industry sector listed in Indonesia). International Journal of Civil Engineering and Technology.9(5), 1305-1320.

Niar, H. (2019). The Impact of Decision Investment, Capital Structure and Growth on Profitability and Company Value in ManufacturingSector of Firms in Indonesia. International Journal of Accounting \& Finance (IJAFAP), 2(1),1-7.

Nilai Perusahaan. Akuntabilitas: Jurnal Ilmu Akuntansi, 10(2), 333 - 348.

Ningsih. P. P., Indarti. I. (2012). Pengaruh Keputusan Investasi, Keputusan Pendanaan, dan Kebijakan Deviden Terhadap Nilai Perusahaan (Studi Kasus Pada Perusahaan Manufaktur yang Terdaftar di Bursa Efek Indonesia Periode 2007-2009). Jurnal Kajian Akuntansi dan Bisnis. 1(1). 1-23.

Nurhayati, I., Poerwati. I., dan Kartika. A. (2019). Dampak Moderasi Profitabilitas dan Leverage Terhadap Pengaruh CSR Pada Nilai Perusahaan Di Indonesia. Prosiding Seminar Nasional Multi Disiplin Ilmu \& Call For Papers Unisbank (SENDI_U).

Pertiwi, P. J., Tommy, P., \& Tumiwa, J. R. (2016). Pengaruh kebijakan hutang, keputusan investasi dan profitabilitas terhadap nilai perusahaan food and beverages yang terdaftar di bursa efek Indonesia. Jurnal EMBA, 4(1), 1369-1380.

Pousette, A., Larsman, P., Hemlin, S., Kauth, M. R., Sullivan, G., Blevins, D., \& Logan, J. (2014). Pengaruh Profitabilitas, Leverage, Dan Ukuran Perusahaan Terhadap Nilai Perusahaan (Perusahaan Manufaktur Sektor Makanan Dan Minuman Yang Terdaftar Di Bursa Efek Indonesia Periode 2012-2016). Implementation Science. https://doi.org/10.4324/9781315853178

Pramana, IGNAD, dan I Ketut Mustanda. (2016). Pengaruh Profitabilitas dan Size Terhadap Nilai Perusahaan Dengan CSR Sebagai Variabel Pemoderasi. E- Jurnal Manajemen Universitas Udayana, 5(1), 561-594.

Purnamasari, L., Nurhayati dan Sofianty, D. (2016). Pengaruh Kualitas Laba dan Kinerja Keuangan terhadap Nilai Perusahaan (Studi pada Perusahaan Manufaktur Sub Sektor Makanan dan Minuman yang Terdaftar di Bursa Efek Indonesia Tahun 2010-2015). Prosiding Akuntansi, 2(2). 606-610.

Putri. M. T. (2017). Pengaruh Profitabilitas dan Keputusan Investasi Terhadap Nilai Perusahaan Pulp \& Paper Yang Terdaftar Di Bursa Efek Indonesia. Jurnal Online Mahasiswa (JOM) Fakultas Ilmu Sosial dan Politik (FISIP), 4(2).

Rachmawati, A.D., Topowijono., \& Sulasmiyati, S. (2015). Pengaruh ukuran perusahaan, profitabilitas, struktur modal, dan keputusan investasi terhadap nilai perusahaan. Jurnal Administrasi Bisnis (JAB), 23(2), 1-7. 
Rahmadianti, D. P., \& Asandimitra, N. (2017). Internal factors, corporate governance, corporate social resposibility disclosure and company value in Indonesia. International Journal of Applied Business and Economic Research, 14 (4), 83-97.

Saputra, D.A. (2013). Pengaruh konservatisma akuntansi dan kualitas laba terhadap nilai perusahaan(Studi Kasus pada Perusahaan Food and Beverages yang Terdaftar di BEI Tahun 2009-2011). Skripsi. Universitas Negeri Yogyakarta

Sari, O. T. (2013). Pengaruh keputusan investasi, keputusan pendanaan dan kebijakan dividen terhadap nilai perusahaan. Management Analysis Journal, 2(2), 1-7.

Sekaran, Umma. (2006) Metodologi Penelitian untuk Bisnis, Edisi 4, Buku 1, Jakarta: Salemba Empat.

Septia, Winda, Ade. (2015). Pengaruh Profitabilitas, Keputusan Investasi, Keputusan Pendanaan, dan Kebijakan Dividen Terhadap Nilai Perusahaan Pada Perusahaan Manufaktur yang Terdaftar di Bursa Efek Indonesia. Skripsi Manajemen Fakultas Ekonomi Universitas Negeri Yogyakarta.

Siallagan, H. (2009). Pengaruh Kualitas Laba Terhadap Nilai Perusahaan. Jurnal Akuntansi Kontemporer, 1(1), 21-32.

Siallagan, Hamonangan dan Mas'ud Machfoedz. 2006. Mekanisme Corporate Governance, Kualitas Laba dan Nilai Perusahaan. Jurnal Simposium Nasional Akuntansi IX Padang: $1-23$.

Sucuahi, W. \& Cambarihan, J. M. (2016). Influence of Profitability to the Firm Value of Diversified Companies in the Philippines. Journal Accounting and Finance Research, $5(2)$.

Sudana, I. M. (2011). Manajemen Keuangan Perusahaan Teori \& Praktik. In Erlangga. https://doi.org/10.1145/2505515.2507827

Sugiyono. (2016). Metode Penelitian Kuantitatif, Kualitatif dan R\&D. Bandung: Alfabeta.

Sujoko, \& Soebiataro, U. (2007). Shareholding Structure influence Leverage Factor Internal And External Factors Against Value Company (empirical study on the manufacturing and non-manufacturing companies in Jakarta Stock Exchange). Journal of Management and Entrepreneurship.

Sukamulja, S. (2004). Good Corporate Governance Di Sektor Keuangan: Dampak GCG Terhadap Kinerja Perusahaan (Kasus di Bursa Efek Jakarta). Jurnal Manajemen Dan Bisnis BENEFIT

Syapruddin, N. S., Prasetianingrum, S. (2015). Analisis Investasi Dan Kualitas Laba Terhadap Nilai Perusahaan. Jurnal Future,215-233.

Triagustina, L., Sukarmanto, E., \& Helliana. (2014). Pengaruh Return On Asset (ROA) Dan Return On Equity (ROE) Terhadap Nilai Perusahaan Pada Perusahaan Manufaktur Subsektor Makanan Dan Minuman Yang Terdaftar Di Bursa Efek Indonesia Periode 2010-2012. Prosiding Akuntansi.

Wiagustini. (2014). Dasar-Dasar Manajemen Keuangan. Edisi Kedua. Denpasar: Udayana University Press.

Yeni, F., \& Mayliza, R. (2017). Kinerja pasar ditinjau dari aspek manajerial keputusan investasi dan kebijakan dividen. Jurnal pundi. https://doi.org/10.31575/jp.v1i1.11

Zuliarni, S. (2012). Pengaruh Kinerja Keuangan Terhadap Harga Saham Pada Perusahaan Mining and Mining Service di Bursa Efek Indonesia (BEI). Jurnal Aplikasi Bisnis. 